\title{
Alicja HruZd-MatuszCZYK
}

\section{Szkoły $z$ polskim językiem nauczania wyzwaniem dla edukacji XXI wieku - wybrane zagadnienia}

Streszczenie: We współczesnej przestrzeni edukacyjnej stałe miejsce znalazły szkoły dla mniejszości narodowych, w tym także Polaków przebywających na obczyźnie. Duża ruchliwość społeczna i duża liczba Polaków przebywających na wychodźstwie sprawia, że konieczne staje się dostosowanie polskiej oferty edukacyjnej dla najmłodszych odbiorców (dzieci i młodzieży), również poza Polską.

W publikacji omawiam znaczenie i konsekwencje współczesnych migracji, charakteryzuję sieć i ofertę szkolnictwa z polskim językiem nauczania, a także omawiam wyniki badań przeprowadzonych w polskich placówkach oświatowych na obczyźnie w wybranych szkołach (w Austrii, Francji oraz Republice Czeskiej), które pozwalają określić główne problemy i oczekiwania rodziców uczniów wobec tych placówek. Opracowanie zamyka podsumowanie. Publikacja stanowi wprowadzenie do szerszych badań nad działalnością i funkcjonowaniem szkół z polskim językiem nauczania na obczyźnie oraz podmiotów silnie związanych z jej działalnością (uczniów, nauczycieli i rodziców).

Słowa kluczowe: szkoły z polskim językiem nauczania na obczyźnie, migracje ludności, edukacja

Wzmożona ruchliwość społeczna początku XXI wieku kształtuje obraz współczesnego społeczeństwa, które staje się coraz bardziej niejednorodne, a odmienności widoczne są w niemal wszystkich obszarach życia. Zmienia się życie społeczne - zwiększa się tempo życia, wyznacznikiem statusu społecznego coraz częściej staje się to, co mamy, a nie to, kim jesteśmy. Zmienia się życie rodzinne - można odnotować coraz większy odsetek związków nieformalnych, w sferze publicznej coraz śmielej pojawiają się informacje o wyborze życia w pojedynkę, część rodzin pozostaje czasowo rozłączona (czasowo niepełna), pojawiają się informacje wieszczące postępujący kryzys małżeństwa i rosnącą akceptację rozwodów (Szukalski, 2017). Zmienia się życie zawodowe - oczekiwania wobec potencjalnych pracowników rosną, cenione są wysokie kwalifikacje, ale przede wszystkim umiejętności. Pra- 
cownik powinien umieć dostosować się do dynamicznego rynku pracy i być gotowy do przekwalifikowania, musi odznaczać się mobilnością, rozumianą jako zgoda na pracę w oddalonym od miejsca zamieszkania mieście lub kraju, by tam kontynuować lub podjąć pracę zawodową. Pracownicy również coraz śmielej przedstawiają pracodawcom swoje oczekiwania związane z pracą na danym stanowisku oraz wykonywanymi zadaniami. Zachodzące zmiany są impulsem przemian w sferze gospodarczej, kulturowej, społecznej, a także a może przede wszystkim - edukacyjnej.

Jednym z wyzwań edukacyjnych jest szkolnictwo mniejszościowe realizujące kształcenie w języku polskim dla osób przebywających poza Polską. Istniejąca sieć polskich szkół pełni ważne role w środowisku pobytu Polaków. $\mathrm{Z}$ jednej strony jest miejscem nauki (języka, historii), z drugiej zaś stanowi ważne ogniwo w kształtowaniu i pielęgnowaniu tożsamości narodowej młodych Polaków zamieszkujących poza granicami Polski. Przedmiotem zainteresowania poczynionym $\mathrm{w}$ prezentowanym opracowaniu są wybrane szkoły z polskim językiem nauczania w Europie z perspektywy rodziców uczniów uczęszczających do tych placówek. Szkoły wpisują się we współczesną przestrzeń edukacyjną, a dzięki prowadzonej działalności są dla Polaków swoistym łącznikiem z krajem i polskością.

\section{Migracje ludności - szkic do rozważań na temat edukacji}

Potrzeba przemieszczania się jest cechą ludzkości. Przyczyny migracji ludności są zróżnicowane w zależności od warunków społecznych, politycznych i gospodarczych oraz okoliczności, w których przyszło żyć ludziom migrującym (np. poczucie bezpieczeństwa vs zagrożenie konfliktem (np. zbrojnym), doświadczenie klęski żywiołowej, odczuwany dostatek vs poczucie braku, potrzeba rozwoju vs stagnacja). Wszystkie wskazane bodźce wędrówek ludności łączy jeden cel - poszukiwanie lepszych warunków życia.

Można przyjąć, że każda migracja jest inna (głównie w zakresie przyczyn wyjazdów i ich skutków). Dotychczasowe ruchy ludności związane były ze zmianą granic państwowych, przymusowym przesiedleniem czy repatriacją. Inne wiązały się z dobrowolną zmianą miejsca zamieszkania (migracje wewnętrzne, często zarobkowe). Bogate doświadczenia migracyjne Polaków przypadają na XX wiek, przy czym ich pobudki są bardzo zróżnicowane. Wspomnę tu o migracjach z początku XX stulecia związanych m.in. z I wojną światową, okupacji hitlerowskiej (lata 40.), destalinizacji (lata 50.), działaniach antysemickich (lata 60.), licznych wyjazdach „turystycznych” zmienia- 
jących się w długoletnie okresy pobytu zarobkowego poza granicami kraju (lata 70.), migracjach politycznych (lata 80.), ale również o zniesieniu restrykcji i liberalizacji paszportowej, która pozwoliła społeczeństwu odzyskać wolność podróżowania (lata 90.). Nieznana dotąd skala wyjazdów Polaków związana była z akcesją Polski do Unii Europejskiej (UE), otwarciem granic państwowych oraz uwolnieniem rynków pracy w krajach europejskich (początek XXI wieku). Na wielkość poakcesyjnego ruchu ludności bezpośrednio oddziaływał kryzys panujący na polskim rynku pracy. Konieczność zarobkowania i nowe możliwości, jakie wiązały się z możliwością podjęcia legalnej pracy zarobkowej poza Polską, sprawiły, że wielu naszych rodaków związało swoją przyszłość (początkowo zarobkową, ale później również życiową) z Wielką Brytanią, Irlandią oraz innymi krajami Europy Zachodniej (por. Ślusarczyk, 2010, s. 16; Danilewicz 2010, s. 80; Danilewicz 2007, s. 152-154).

Dokładna liczba migrantów jest trudna do oszacowania, ponieważ część Polaków nie legalizuje swojego pobytu za granicą i np. podejmuje pracę w „szarej strefie”, część osób legalizuje pobyt, choć wcześniej był on nielegalny, niektóre statystyki pomijają zagraniczne wyjazdy sezonowe, stąd trudność w doprecyzowaniu liczby migrantów, a wszelkie posiadane dane są danymi szacunkowymi (Walczak, Kozdrowicz, Bielecka, 2009, s. 201). W ostatnich latach można było zaobserwować pewne wahania w liczbie osób migrujących. Znaczący wzrost przypada - rzecz jasna - na początkowy okres członkostwa Polski w UE. Szacunkowe dane GUS na koniec 2017 roku wskazują, że poza granicami Polski przebywało czasowo ok. 2540 tys. Polaków (www-2).

Możliwości migracji poakcesyjnej zmieniły dotychczasowe preferencje wyjeżdżających. Choć początkowo Polacy w wyjazdach zagranicznych kierowali się głównie na Wyspy Brytyjskie, to również inne kraje cieszyły się ich zainteresowaniem. Jak kształtowały się preferencje migracyjne Polaków w okresie przed-i poakcesyjnym, ilustruje poniższa mapa w opracowaniu Marty Mioduszewskiej.

Najpopularniejszym kierunkiem wyjazdów stałych Polaków od wielu lat były Niemcy. Włochy oraz Stany Zjednoczone plasowały się na kolejnych pozycjach. Po przystąpieniu Polski do UE pozycję lidera Niemcy oddały Wielkiej Brytanii. Coraz chętniej wyjeżdżający Polacy kierowali się w stronę Irlandii. Niezmiennym zainteresowaniem - jak widać na załączonej mapie cieszyły się również pozostałe europejskie kraje. Wciąż popularne - choć na wyraźnie mniejszą skalę niż kontynentalne migracje - pozostają wyjazdy do krajów pozaeuropejskich (Stany Zjednoczone, Kanada) (Szczygielska, 2013, s. 90). Zmiana przepisów regulujących możliwość bezwizowego wjazdu na 
teren Stanów Zjednoczonych (obecnie krótkoterminowego) może w przyszłości zachwiać wyborem kierunku wyjazdów czasowych Polaków.

Tabela 1. Kierunki emigracji z Polski przed i po 1 maja 2004 roku

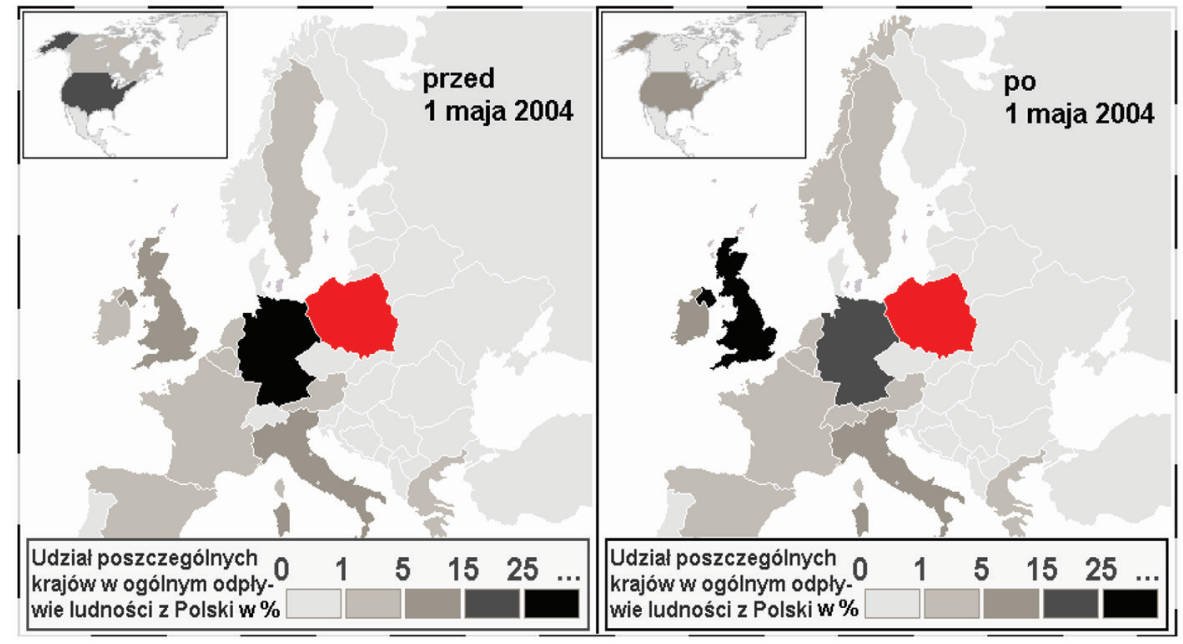

Źródło: opracowano przez M. Mioduszewską na podstawie BAEL/OBM (Mioduszewska, 2008, s. 32).

Jak każda zmiana, również migracja niesie za sobą pewne konsekwencje. Jerzy Nikitorowicz i Dorota Misiejuk podkreślają, że zarówno sposób migracji, jej przyczyny i dynamika oddziałują na tożsamość grupy, jej pamięć zbiorową oraz przyjmowany styl życia. Migracja odciska swoje piętno nie tylko na osobach migrujących, ale również na kolejnych pokoleniach (Nikitorowicz i Misiejuk, 2009, s. 9).

Na społeczne konsekwencje migracji zwrócił uwagę Komitet Badań nad Migracjami PAN. Raport opracowywany przez Komitet wskazuje na wystąpienie problemów, których konsekwencje będą odczuwane coraz dotkliwiej w kolejnych dziesięcioleciach przez całe polskie społeczeństwo. Przede wszystkim wyraźnie obniża się (i tak niska) liczba urodzeń. Co ciekawe, jak pokazują badania prowadzone przez Komitet, dzietność Polek mieszkających za granicą jest dwukrotnie wyższa niż pozostających w kraju (!). Polskę opuszczają głównie ludzie młodzi, którzy nie zawsze wiążą swoją przyszłość z powrotem do kraju. W związku z powyższym struktura społeczeństwa zmienia się, rośnie liczba starszych Polaków (65 lat i więcej). Marek Okólski (przewodniczący Komitetu) podkreśla, że konsekwencje migracji sięgają 
przede wszystkim rodziny, która silnie odczuwa zachodzące przemiany - rośnie liczba rozwodów, widoczny staje się rozpad rodzin wielopokoleniowych. W kraju pozostają seniorzy rodzin, w związku z tym w przyszłości konieczna będzie taka organizacja opieki instytucjonalnej dla tej grupy, która wypełni lukę pojawiającą się po odpływie młodszego pokolenia, które dotąd sprawowało opiekę nad starszymi w środowisku rodzinnym (www-3; www-4).

Reasumując, na skutek migracji systematycznie obniża się liczba mieszkańców Polski, spada liczba urodzeń (mimo usilnych działań rządowych wspierających rodziny programami socjalnymi) oraz starzeje się społeczeństwo. Wszystkie te czynniki już teraz silnie oddziałują na rozwój społeczno-gospodarczy Polski oraz poszczególnych jej regionów, a negatywne skutki mogą być odczuwane w przyszłości coraz mocniej.

Ruchy ludności nie pozostają obojętne również wobec edukacji. Edukacyjne konsekwencje migracji możemy rozpatrywać dwubiegunowo. Po pierwsze należy wskazać skutki migracji dla rodzimej edukacji - ubytek uczniów w krajowych szkołach, indywidualne konsekwencje migracji rodzinnych dla uczniów pozostających w kraju (rozłączenie rodziny). Po drugie możemy mówić o konieczności rozwoju szkolnictwa mniejszościowego - w tym przypadku szkolnictwa z polskim językiem nauczania - w kraju wychodźstwa.

W pierwszym przypadku, kiedy analizujemy konsekwencje migracji dla uczniów w wymiarze indywidualnym, możemy uogólnić i wskazać trzy główne grupy problemów, które dotyczą dzieci i młodzieży doświadczającej (pośrednio i bezpośrednio) migracji są to problemy:

- pedagogiczne, kiedy wyniki w nauce osiągane przez uczniów pozostają na poziomie przeciętnym bądź słabym,

- społeczne, gdy na skutek braku rodziców uczniowie przejawiają formy zachowania aspołecznego,

- psychologiczne, w tym przypadku zaburzona zostaje równowaga emocjonalna dziecka - na podstawie prowadzonych badań stwierdza Maria Leśniak (Leśniak, 2009, s. 133).

Zjawisko migracji społecznych często - nie bez przyczyny - kojarzone jest z negatywnymi konsekwencjami, których przykłady wymieniono powyżej. Samo działanie (wyjazd) jest efektem poczucia braku (np. pracy czy życiowego dostatku), wiąże się z chęcią podniesienia jakości życia, a także z możliwościami, jakie przyniosła swoboda podróżowania i funkcjonowanie z strukturach UE. Należy pamiętać, że przemieszczanie się ludności ma również pozytywne aspekty. Jednym z nich jest łagodzenie objawów kryzysów gospodarczych, obniżenie stopy bezrobocia - przesunięcie pracowników 
tam, gdzie aktualnie jest na nich zapotrzebowanie, podnoszenie kwalifikacji/przekwalifikowanie zależności od potrzeb rynku pracy, wzrost stopy życiowej ludności, podtrzymanie osiągniętego poziomu życia, zakup trwałych dóbr konsumpcyjnych czy poprawa warunków mieszkaniowych (Danilewicz, 2007, ss. 156-157; Danilewicz, 2006, s. 33).

\section{Sieć szkolnictwa dla Polaków przebywających za granicą - na przykładzie szkół z polskim językiem nauczania}

W każdej mniejszości przebywającej za granicą jest tęsknota za krajem pochodzenia, którą może - choć w części - kompensować kontakt ze szkołą narodową, choć mniejszościową, w której pielęgnowany jest język, podtrzymywane są tradycje i przekazywana jest kultura kraju ojczystego.

Tadeusz Lewowicki podkreśla doniosłą rolę i znaczenie oświaty, która obok rodziny i Kościoła, a także środków masowego komunikowania - odgrywa ważną rolę w przekazie kultury. Uświadomienie sobie znaczenia szkoły jako instytucji ważnej dla funkcjonowania grup mniejszościowych sprawia, że coraz częściej zabiegają one o pracę tych placówek w różnych środowiskach społecznych oraz dbają o ich warunki funkcjonowania. Z pomocą przychodzą regulacje prawne o zasięgu międzynarodowym oraz krajowym, które określają możliwości nauki (m.in. języków) i rozwoju (kultury) grup mniejszościowych w danym kraju (Lewowicki, 2013, ss. 11-12).

Szkolnictwo polskie za granicą wypracowało sobie długoletnią tradycję swojej działalności sięgającą początku XX wieku. To właśnie w tym czasie zaczęto troszczyć się o Polaków, którzy po przemianach zachodzących w kraju (odzyskanie niepodległości) pozostali poza jego granicami. W działalności szkół polskich konieczne były liczne reformy (m.in. zmiana form organizacji szkół ${ }^{1}$ ), jednak cel ich działalności pozostaje bez zmian (Koprukowniak, 1995, s. 12). Przemiany, których doświadcza szkolnictwo polskie za granicą, dotyczą również innych grup etnicznych znajdujących się w kraju pobytu. Są to czynniki niezależne od samej instytucji (czynniki zewnętrzne). Dodatkowo na szkołę oddziałują bodźce właściwe grupie Polaków, społeczności tworzącej szkołę (czynniki wewnętrzne), które budują jej strukturę i tworzą właściwą szkole atmosferę.

1 Początki sięgają szkolnictwa parafialnego, przemiany doprowadziły do powstania innych form organizacji polskich szkół, o których mowa w dalszej części opracowania. 
Uczniowie, którzy przebywają poza Polską, realizują obowiązek szkolny i obowiązek nauki w lokalnym systemie edukacji kraju zamieszkania. Natomiast - zgodnie z założeniami - kształcenie dodatkowe odbywa się w polskich szkołach, w których uczniowie podejmują edukację uzupełniającą w zakresie nauki języka polskiego, historii, geografii Polski oraz ewentualnie innych przedmiotów (www-5, s. 2).

Sieć szkół z polskim językiem nauczania na obczyźnie przybiera aktualnie następujące formy działalności:

- Szkoty polskie przy placówkach dyplomatycznych - Szkolne Punkty Konsultacyjne przy Ambasadach RP - działają w 37 krajach. Według danych z roku szkolnego 2013/2014 naukę w tych szkołach pobierało 15,8 tys. uczniów ${ }^{2}$. W roku szkolnym 2014/2015 naukę w szkołach przy polskich placówkach dyplomatycznych kontynuowało łącznie 15,9 tys. uczniów. W kolejnych latach (rok szkolny 2015/2016 i 2016/2017) odnotowano wzrost liczby uczniów, których było już 17 tys. Początkowo działalność szkół skierowana była do dzieci dyplomatów, jednak od 1992 roku szkoły otwarto również dla innych osób na stałe zamieszkujących poza granicami Polski. W działalność tych placówek wpisana jest realizacja sztywnego programu nauczania. Placówki zatrudniają łącznie ok. 600 nauczycieli.

- Szkoły społeczne - najczęściej są to tzw. szkoły sobotnie prowadzone głównie przez organizacje pozarządowe, polonijne organizacje oświatowe, stowarzyszenia rodziców oraz polskie parafie. "Szkoły sobotnie” - w przeciwieństwie do SPK - same decydują o programach nauczania i zatrudnieniu nauczycieli. Z deklaracji 402 szkół wynika, że kształcą one 31 tys. uczniów.

- Sekcje polskie w szkołach międzynarodowych:

- nauczanie wszystkich przedmiotów odbywa się w języku polskim w klasach I-IV lub I-XII (np. Litwa, Ukraina, Łotwa, Białoruś, Czechy, Mołdawia);

- nauka języka polskiego oraz przedmiotów ojczystych prowadzona jest w systemie oddziałów dwujęzycznych w sekcjach polskich we Francji

2 „W skład szkół wchodzą: Zespół Szkół w Atenach, 59 szkolnych punktów konsultacyjnych (SPK), 9 filii SPK. Szkoły realizują program uzupełniający (przedmioty ojczyste), z wyjątkiem Zespołu Szkół w Atenach, który prowadzi również nauczanie ramowe". Źródło: http://www.polska-szkola.pl/index.php/dla-rodzicow/oswiata-polonijna. 20.08.2019 (www-6). 
lub jako przedmiot obowiązkowy w kilku szkołach w Rosji (m.in. Petersburg, Usole Syberyjskie), na Białorusi, Ukrainie i Łotwie;

- język polski nauczany jest w ramach zajęć dodatkowych m.in. w: Danii, Szwecji, Norwegii, Niemczech, Węgrzech, Australii, Rumunii, Rosji, Ukrainie, Białorusi oraz Kazachstanie.

- Szkoły Europejskie - powstały dwie sekcje polskie - w Luksemburgu oraz Brukseli. W szkołach tych uczą się dzieci (ok. 380 osób) pracowników agend Komisji Europejskiej.

- Szkoty im. Komisji Edukacji Narodowej w Ośrodku Rozwoju Polskiej Edukacji za Granica (ORPEG) w Warszawie - w systemie nauczania na odległość (realizującym program ramowy i uzupełniający) na wszystkich poziomach edukacyjnych (szkoła podstawowa, gimnazjum i liceum ogólnokształcące) kształci się ok. 700 uczniów (www-6; www-7; www-8).

Wzrost liczby polskich migrantów sprawia, że szkoły prowadzące nauczanie w języku polskim cieszą się coraz większym zainteresowaniem Polaków mieszkających za granicą, ich działalność poddawana jest licznym ocenom, a praca (instytucji, nauczycieli, organizacji kierujących jej działalnością w przypadku stowarzyszeń i in.) weryfikacji. Rozpatrując działalność szkół z polskim językiem nauczania na obczyźnie oraz uwzględniając specyfikę środowiska tworzącego te szkoły, niezwykle istotne jest uświadomienie sobie, że „środowisko polonijne, to żywy organizm, w skład którego wchodzą wciąż nowe grupy Polaków, pragnące utrzymywać naturalne związki z krajem rodzinnym. Im także szkoła polonijna jest potrzebna, podobnie jak nauka w kraju osiedlenia, aby łatwiej znosić okres adaptacji do nowego środowiska, do nowych warunków kulturowych i obyczajowych oraz odmiennych warunków przejawiających się w postawach mentalności i zachowaniu w życiu codziennym, domu i pracy. Jest to bardzo istotne w odniesieniu do dzieci i młodzieży niż dorosłych, którzy wyjechali z kraju z określonym kanonem wartości, w tym także wartości mieszczących się w pojęciu świadomości narodowej i narodowej kultury. (...) Ten naturalny związek jest konieczny dla podtrzymania i utrzymania narodowej tożsamości, odrębności etnicznej, tych wyróżników bogactwa narodowej kultury spośród innych. Oświata i kontakt z mową ojczystą i językiem polskim nie mogą stanowić bariery we wchodzeniu w nowe środowisko, a jednocześnie winny stanowić ważne ogniwo w zachowaniu pierwiastków polskości wśród innych grup etnicznych" (Koprukowniak, 1995, ss. 12-13) - podkreśla Albin Koprukowniak.

Zenon Jasiński zaznacza, że ważnym zadaniem szkoły z polskim językiem nauczania poza granicami kraju jest funkcjonowanie razem ze społeczeństwem 
większościowym (a nie obok niego) i przygotowanie jednostki do życia w państwie pobytu. Szkoła powinna stanowić pomost pomiędzy kulturą polską w kraju, kulturą światową oraz kulturą kraju pobytu. Jednocześnie zadaniem szkoły jest zachowanie odpowiednich proporcji w realizacji dwóch funkcji - narodowej i obywatelskiej w taki sposób, by nie wypaczyć obrazu kraju pochodzenia przodków (a często również samych uczniów) (Jasiński, 2010, ss. 28-32).

Na koniec pragnę zaznaczyć, że działalność szkół z polskim językiem nauczania jest jednym z zadań realizowanych przez Ministerstwo Edukacji Narodowej na rzecz Polaków przebywających poza granicami kraju. Tak długo jak Polacy będą obecni w innych krajach, tak długo konieczne będzie dbanie o polską edukację za granicą, która zapewnia kontakt i ciągłość języka, kultury i wiedzy o Polsce.

\section{Perspektywy i oczekiwania dla/wobec polskiego szkolnic- twa mniejszościowego - wyniki badań własnych}

Działalność szkół z polskim językiem nauczania, a zwłaszcza wszystkie zmiany - planowane bądź wprowadzane - budzą wiele emocji, głównie wśród osób bezpośrednio zainteresowanych ich funkcjonowaniem. Polskie szkoły nie powinny być skostniałym konstruktem historycznym, a prowadzona działalność powinna być dostosowana do oczekiwań podmiotów z nią związanych (uczniów, nauczycieli i rodziców) oraz do zmieniającej się rzeczywistości społecznej. W związku z powyższym istotne wydaje się przeprowadzenie diagnozy dotyczącej oceny działalności tych placówek oraz wskazania oczekiwań osób związanych z jej pracą.

Celem podjętych badań i ich opracowania było poznanie opinii rodziców na temat wybranych obszarów funkcjonowania szkół z polskim językiem nauczania na obczyźnie, w tym głównie wskazanie:

- Jak rodzice uczniów uczęszczających do szkół z polskim językiem nauczania oceniają działalność tych placówek?

- Jakie są oczekiwania dotyczące funkcjonowania szkół z polskim językiem nauczania w relacjach rodziców?

Badania diagnostyczne przeprowadzono w trzech Szkolnych Punktach Konsultacyjnych przy Ambasadach RP w Austrii (Wiedeń), Republice Czeskiej (Praga) oraz Francji (Paryż), a także w szkole polskiej w Republice Czeskiej (Czeski Cieszyn) ${ }^{3}$. Przygraniczny charakter szkoły w Czeskim Cieszynie i forma prowadzonej działalności (szkoła realizuje czeski program nauczania

3 Badania zostały sfinansowane ze środków Narodowego Centrum Nauki. 
w języku polskim) sprawia, że jest ona instytucją porównawczą wobec szkół działających przy ambasadach. Przeprowadzone badania stanowią wprowadzenie do szerszych badań społeczności szkół z polskim językiem nauczania na obczyźnie zamieszkujących środowiska niejednorodne kulturowo ${ }^{4}$.

W badaniach uczestniczyło 174 rodziców uczniów szkół podstawowych oraz gimnazjalnych. Charakterystykę badanej grupy ilustrują poniższe dane ujęte w zestawienia tabelaryczne.

Tabela 2. Struktura badanej grupy według miejsca zamieszkania respondentów

\begin{tabular}{|l|c|c|c|c|c|}
\hline \multicolumn{1}{|c|}{ Typ szkoły/kraj } & Austria & Francja & R.C. - Praga & R.C. - Cz. Cieszyn & Ogółem \\
\hline Szkoła podstawowa & $14(43,8 \%)$ & $44(84,6 \%)$ & $5(55,6 \%)$ & $52(64,2 \%)$ & $115(66,1 \%)$ \\
\hline Gimnazjum & $18(56,2 \%)$ & $8(15,4 \%)$ & $4(44,4 \%)$ & $29(35,8 \%)$ & $59(33,9 \%)$ \\
\hline Ogółem & $32(100 \%)$ & $52(100 \%)$ & $9(100 \%)$ & $81(100 \%)$ & $174(100 \%)$ \\
\hline
\end{tabular}

Źródło: opracowanie własne.

Uczestniczący w badaniu respondenci mieszkający we Francji oraz na obszarze czeskiego Zaolzia to rodzice w przeważającej grupie wiekowej 30-39 lat. Natomiast w Austrii oraz Pradze przeważają rodzice w przedziale wiekowym 40-49 lat.

Tabela 3. Respondenci biorący udział w badaniu według wieku

\begin{tabular}{|l|c|r|r|r|}
\hline Wiek respondentów/kraj & \multicolumn{1}{|c|}{ Austria } & \multicolumn{1}{|c|}{ Francja } & R.C. - Praga & R.C. - Cz. Cieszyn \\
\hline Od 25 do 29 lat & - & $2(2,5 \%)$ & $1(7,1 \%)$ & $6(4,5 \%)$ \\
\hline Od 30 do 39 lat & $14(30,4 \%)$ & $46(56,8 \%)$ & $5(35,7 \%)$ & $64(48,1 \%)$ \\
\hline Od 40 do 49 lat & $22(47,9 \%)$ & $28(34,6 \%)$ & $8(57,1 \%)$ & $55(41,4 \%)$ \\
\hline Od 50 do 59 lat & $10(21,7 \%)$ & $5(6,1 \%)$ & - & $8(6 \%)$ \\
\hline Ogółem & $46(100 \%)$ & $81(100 \%)$ & $14(100 \%)$ & $133(100 \%)$ \\
\hline
\end{tabular}

Źródło: opracowanie własne.

Na uwagę zasługuje fakt, że wszyscy respondenci z Pragi deklarują posiadanie dyplomu wyższej uczelni (100\%). Również wysokie, choć nieco bardziej zróżnicowane wykształcenie deklarują rodzice z Austrii oraz Czeskiego Cieszyna. Wyraźnie odznaczają się deklaracje rodziców z Francji, którzy mają niższe wykształcenie od pozostałych respondentów.

4 Wyniki przeprowadzonych badań szerzej omówiono w publikacji Gajdzica, A., Piechaczek-Ogierman, G. i Hruzd-Matuszczyk, A. 2014. Edukacja na obczyźnie postrzegana $z$ perspektywy dzieci, rodziców i nauczycieli ze szkót z polskim językiem nauczania. Toruń: Wydawnictwo Adam Marszałek.

5 W tabeli ujęto średni wiek obojga rodziców zgodnie z deklaracją respondentów. 
Tabela 4. Respondenci biorący udział w badaniu według wykształcenia ${ }^{6}$

\begin{tabular}{|l|r|r|r|r|}
\hline Wykształcenie respondentów/kraj & \multicolumn{1}{|c|}{ Austria } & \multicolumn{1}{|c|}{ Francja } & R.C. - Praga & R.C. - Cz. Cieszyn \\
\hline Podstawowe & - & - & - & $1(0,7 \%)$ \\
\hline Zasadnicze zawodowe & $2(4,3 \%)$ & $17(20,5 \%)$ & - & $4(3 \%)$ \\
\hline Średnie (zawodowe i ogólne) & $18(39,1 \%)$ & $44(53 \%)$ & - & $61(45,2 \%)$ \\
\hline Wyższe & $26(56,6 \%)$ & $22(26,5 \%)$ & $13(100 \%)$ & $67(49,6 \%)$ \\
\hline Inne - pozostałe & - & - & - & $2(1,5 \%)$ \\
\hline Ogółem & $46(100 \%)$ & $83(100 \%)$ & $13(100 \%)$ & $135(100 \%)$ \\
\hline
\end{tabular}

Źródło: opracowanie własne.

Zebrane dane i uzyskane wyniki nie wskazują na znaczące różnice w opiniach rodziców uczniów szkół podstawowych i gimnazjów w dalszej części opracowania dane podaję łącznie dla obu typów szkół.

Uczniowie przebywający poza granicami kraju rozpoczynają naukę w lokalnych systemach oświaty, a szkoły prowadzące nauczanie w języku polskim stanowią dla nich edukację uzupełniającą. W związku z powyższym uczniowie oraz rodzice mogą oceniać i porównywać jakość i formę kształcenia w obu typach szkół. Jak rodzice oceniają szkoły polskie? Ogólna ocena wystawiona przez respondentów jest dobra (Wiedeń - 46,9\%, Paryż - 62,3\%, Praga - 50\%). Ocena szkoły dokonana przez rodziców z Czeskiego Cieszyna jest wyższa w porównaniu z poprzednimi deklaracjami, gdyż aż 67,1\% deklaracji potwierdza bardzo dobrą ocenę działalności polskiej szkoły. Warto zaznaczyć, że szkoła polska w Czeskim Cieszynie cieszy się dobrą opinią i zyskuje wysoką ocenę również w środowisku lokalnym (także po polskiej stronie granicy państwowej).

Tabela 5. Ocena działalności szkół z polskim językiem nauczania w deklaracjach rodziców uczniów tych szkół

\begin{tabular}{|l|r|r|r|r|}
\hline Ocena działalności szkoły/kraj & \multicolumn{1}{|c|}{ Austria } & \multicolumn{1}{c|}{ Francja } & R.C. - Praga & R.C. - Cz. Cieszyn \\
\hline Bardzo dobra & $11(34,4 \%)$ & $13(24,5 \%)$ & - & $53(67,1 \%)$ \\
\hline Dobra & $15(46,9 \%)$ & $33(62,3 \%)$ & $4(50 \%)$ & $22(27,8 \%)$ \\
\hline Przeciętna & $5(15,6 \%)$ & $6(11,3 \%)$ & $2(25 \%)$ & $4(5,1 \%)$ \\
\hline Dostateczna & $1(3,1 \%)$ & $1(1,9 \%)$ & $2(25 \%)$ & - \\
\hline Niedostateczna & - & - & - & - \\
\hline Ogółem & $32(100 \%)$ & $53(100 \%)$ & $8(100 \%)$ & $79(100 \%)$ \\
\hline
\end{tabular}

Źródło: opracowanie własne.

${ }^{6}$ W tabeli ujęto wykształcenie obojga rodziców zgodnie z deklaracją respondentów. 
Choć rodzice pozytywnie oceniają działalność szkół z polskim językiem nauczania, nie pozostają bezkrytyczni wobec problemów, z którymi szkoła musi się mierzyć. Problemy wyróżnione przez rodziców można podzielić na dwie grupy - wewnętrzne i zewnętrzne.

Tabela 6. Problemy szkół z polskim językiem nauczania w opinii rodziców

\begin{tabular}{|l|r|r|r|r|}
\hline \multicolumn{1}{|c|}{ Problemy szkół/kraj } & \multicolumn{1}{c|}{ Austria } & \multicolumn{1}{c|}{ Francja } & \multicolumn{1}{c|}{ R.C. - Praga } & R.C. - Cz. Cieszyn \\
\hline Niechęć władz lokalnych & $1(2,8 \%)$ & $15(39,5 \%)$ & $2(16,7 \%)$ & $5(5,8 \%)$ \\
\hline Niechęć społeczności & $7(19,4 \%)$ & $4(10,5 \%)$ & $2(16,7 \%)$ & $23(26,7 \%)$ \\
\hline Zbyt mała liczba uczniów & $6(16,7 \%)$ & $2(5,3 \%)$ & $3(25 \%)$ & $46(53,6 \%)$ \\
\hline $\begin{array}{l}\text { Niechęć rodziców do włączenia się } \\
\text { w pracę szkoły }\end{array}$ & $12(33,3 \%)$ & $14(36,8 \%)$ & $2(16,7 \%)$ & $7(8,1 \%)$ \\
\hline Inne & $10(27,8 \%)$ & $3(7,9 \%)$ & $3(25 \%)$ & $5(5,8 \%)$ \\
\hline Ogółem & $36(100 \%)$ & $38(100 \%)$ & $12(100 \%)$ & $86(100 \%)$ \\
\hline
\end{tabular}

Źródło: opracowanie własne.

W pierwszej znajdą się problemy związane z jej codziennym funkcjonowaniem, a zatem liczba uczniów i praca rodziców na rzecz szkoły. W drugiej można przywołać stosunek społeczności lokalnej oraz władz do działalności szkoły. Rodzice z Austrii (33,3\%) i Francji (36\%) podkreślają niechęć rodziców do włączenia się w pracę szkoły ${ }^{7}$. Sami więc wskazują siebie jako grupę, która może oddziaływać negatywnie i nie sprzyjać prężnemu działaniu szkoły oraz integracji społeczności szkolnej. Respondenci z Republiki Czeskiej (Praga) wskazują liczbę uczniów jako źródło potencjalnych (kwestia rentowności) i realnych problemów szkół (zbyt mała liczba uczniów w klasach). Rodzice uczniów z Czeskiego Cieszyna zaznaczali i uzupełniali swoje deklaracje o fakt, że rozumieją swoje odpowiedzi jako "malejącą liczbę uczniów”. Jest to problem dotykający nie tylko szkoły polskiej w Czeskim Cieszynie, ale wszystkich szkół, również tych po drugiej stronie Olzy. Wśród licznych problemów określonych jako „inne” rodzice najczęściej wskazywali niechęć władz państwowych do działalności szkół polskich na obczyźnie wyrażającej się w cięciach finansowych, malejącej liczbie godzin dydaktycznych oraz obniżaniu rangi szkół prowadzonych przy placówkach dyplomatycznych.

Oczekiwania rodziców wobec szkół z polskim językiem nauczania, do których uczęszczają ich dzieci, są podobne mimo różnych doświadczeń życio-

7 Takie deklaracje wynikają $\mathrm{z}$ faktu uczestnictwa w badaniach dużej grupy rodziców-nauczycieli, którzy wyrazili opinię zgodną z ich wiedzą zawodową oraz perspektywą rodzicielską, którą reprezentują. 
wych, zawodowych i środowiskowych w miejscu zamieszkania. Oczekiwania respondentów można uszeregować w trzech grupach:

- dotyczących funkcjonowania szkół z polskim językiem nauczania jako takich,

- dotyczących programów nauczania, działań realizowanych w szkołach i jakości kształcenia,

- dotyczących organizacji pracy szkoły.

W deklaracjach, które znajdują się w pierwszej grupie, przede wszystkim rodzice podkreślają, że najbardziej zależy im na przetrwaniu i kontynuowaniu działalności polskich szkół poza granicami Polski. O szkołach polskojęzycznych rodzice mówią:

- „żeby istniały jak najdłużej” (Austria),

- „żeby istniały nadal i były lepiej dofinansowane” (Austria),

- „aby kontynuowały swoją pracę” (Francja),

- „aby działały jak do tej pory” (Francja),

- „żeby były kontynuowane” (Praga),

- „żeby nie zniknęły” (Czeski Cieszyn).

Respondenci podkreślają, że nie bez znaczenia jest dla nich również praca i inicjatywy podejmowane przez szkołę, główne cele jej działalności oraz jakość kształcenia w placówkach z polskim językiem nauczania. Wśród najczęstszych i powtarzających się opinii rodziców można wyróżnić następujące:

- „chcę, aby dziecko wiedziało o kraju pochodzenia i jego kulturze” (Austria),

- „dostosowanie programu do potrzeb dzieci uczących się za granicą" (Austria),

- „oczekuję, że dzieci będą uczyły się historii oraz języka polskiego, poznawały matematykę w języku polskim" (Austria),

- „chcę, aby dzieci pobierały rzetelną naukę języka polskiego, historii i geografii kraju" (Francja),

- „aby dzieci poznały język, kulturę i obyczaje kraju ojczystego” (Francja),

- „zwiększenie wymagań wobec uczniów” (Francja),

- „edukacja na właściwym poziomie” (Francja),

- „żeby szkoła realizowała program dzisiejszej szkoły” (Praga),

- „szkoła powinna podtrzymywać kontakt z pięknym literackim językiem polskim, podtrzymywać tradycje polskie" (Praga),

- „aby szkoła rozpowszechniała język i kulturę polską” (Czeski Cieszyn),

- "gwarancji wysokiej jakości kształcenia - fachowość nauki, kultury nauczania" (Czeski Cieszyn), 
- „oczekuję większej ilości kontaktów ze współczesną kulturą, językiem polskim" (Czeski Cieszyn),

- „aby szkoły informowały o współczesnym życiu społecznym, politycznym i kulturalnym w Polsce" (Czeski Cieszyn).

Do trzeciej - według przyjętego podziału - grupy zaliczam opinie rodziców odnoszące się do pracy organizacyjnej szkoły, gdzie rodzice jasno formułują to, czego ich zdaniem brakuje lub co niedomaga. W poprawie wizerunku szkoły mogłyby pomóc następujące działania:

- "centralna lokalizacja szkoły i łatwy dojazd komunikacją miejską" (Austria),

- „żeby szkoła była szkołą, a nie punktem konsultacyjnym” (Austria),

- „zwiększenie liczby godzin lekcyjnych” (Francja),

- "chcę, aby było więcej imprez, więcej Polski” (Francja),

- "aby imprezy kulturalne nie odbywały się kosztem lekcji” (Praga),

- „organizacja imprez kulturalnych, prowadzenie kół zainteresowań” (Czeski Cieszyn),

- „aby szkoły potrafiły pomóc Polakom za granicą" (Czeski Cieszyn).

W zaprezentowanych opiniach można zauważyć potrzebę prowadzenia szkół z polskim językiem nauczania dla rodzin przebywających za granicą. Dzięki temu podtrzymują oni kontakt z Polską, a uczęszczanie dzieci do szkół sprawia, że rodzice mają poczucie wypełnienia obowiązku patriotycznego wobec dzieci i Ojczyzny. Dla rodziców ważne jest to, by nauczanie odbywało się na odpowiednim poziomie, który w przyszłości może pozwolić na kontynuowanie nauki w Polsce. Nie bez znaczenia są również treści przekazywane w szkole. Rodzice podkreślają konieczność wypracowania w uczniach znajomości literackiego języka polskiego oraz historii i kultury kraju pochodzenia. Warto zaznaczyć, że rodzice dostrzegają potrzebę kontaktu ze współczesną Polską, jej kulturą i życiem społecznym. W trzeciej grupie - zawierającej najbardziej przyziemne oczekiwania rodziców wobec szkoły - respondenci wskazywali, że szkoła polska straciła swoją rangę przez zmianę jej pozycji na szkolny punkt konsultacyjny. Rodzice uczniów z Czeskiego Cieszyna deklarują chęć prowadzenia w szkole zajęć pozalekcyjnych - taka potrzeba wynika z charakteru działalności i organizacji pracy szkoły. Uczniowie związani ze szkolnymi punktami konsultacyjnymi zajęcia w polskiej szkole traktują już

8 Wiedeńska szkoła umiejscowiona jest na obrzeżach miasta, dojazd do niej jest utrudniony i czasochłonny. Dodatkowo wielu uczniów dojeżdża do szkoły spoza Wiednia, co wymaga ogromnego zaangażowania i determinacji rodziców. 
jako swoją dodatkową pracę, gdyż regularne zajęcia lekcyjne pobierają w innych szkołach większościowych (państwowych bądź prywatnych).

Część respondentów deklarowała, że praca realizowana aktualnie przez szkołę jest według nich wystarczająca i nie należy wprowadzać zmian, ich oczekiwania i wymagania są zaspokojone.

Każda odpowiednio prowadzona placówka może usprawnić swoje działanie i stać się bardziej atrakcyjna dla swoich adresatów. Również rodzice dostrzegają możliwości usprawnienia działania polskich szkół. Choć część respondentów przyznaje, że w szkołach nie trzeba wprowadzać zmian (Francja - 20\%, Praga - 20\%, Czeski Cieszyn - 36,9\%), to jednak zaznaczają, że każde nowe działanie może być dla szkoły pozytywne i ewentualne wdrożenie tych inicjatyw może usprawnić jej działalność. Respondenci z Wiednia (16,7\%) i Pragi (20\%) wskazali możliwość nauczania uczniów języka kraju pobytu jako działalność obustronnie korzystną. W opiniach rodziców związanych z wiedeńską szkołą pojawiają się również konkretne wskazówki-propozycje dla szkól, są to: większe wsparcie ze strony polskiego rządu, zbudowanie szkoły atrakcyjnej dla uczniów, zmniejszenie liczebności klas, dostosowanie programu nauczania, pokazanie władzy, jak ważna jest polska szkoła dla dzieci.

Tabela 7. Propozycje działań szkół z polskim językiem nauczania w opiniach rodziców uczniów.

\begin{tabular}{|l|r|r|r|r|}
\hline \multicolumn{1}{|c|}{ Propozycje działań/kraj } & \multicolumn{1}{c|}{ Austria } & \multicolumn{1}{c|}{ Francja } & R.C. - Praga & R.C. - Cz. Cieszyn \\
\hline Zaangażowanie społeczności szkoły & $3(10 \%)$ & $8(16 \%)$ & $2(13,3 \%)$ & $5(7,7 \%)$ \\
\hline Zaangażowanie społeczności lokalnej & - & $2(4 \%)$ & $1(6,7 \%)$ & $4(6,2 \%)$ \\
\hline $\begin{array}{l}\text { Zaangażowanie lokalnych instytucji } \\
\text { pozaszkolnych }\end{array}$ & $3(10 \%)$ & $3(6 \%)$ & $3(20 \%)$ & $9(13,8 \%)$ \\
\hline Oferta działań skierowana do rodziców & $2(6,7 \%)$ & $5(10 \%)$ & - & $7(10,8 \%)$ \\
\hline $\begin{array}{l}\text { Nauka języka narodowego kraju pobytu } \\
\text { dla uczniów }\end{array}$ & $5(16,7 \%)$ & $5(10 \%)$ & $3(20 \%)$ & $3(4,6 \%)$ \\
\hline $\begin{array}{l}\text { Nauka języka narodowego kraju pobytu } \\
\text { dla rodziców }\end{array}$ & $2(6,7 \%)$ & $5(10 \%)$ & $3(20 \%)$ & $2(3,1 \%)$ \\
\hline Wrzystkie & $4(13,3 \%)$ & $8(16 \%)$ & - & $10(15,4 \%)$ \\
\hline Nie trzeba wprowadzać zmian & $4(13,3 \%)$ & $10(20 \%)$ & $3(20 \%)$ & $24(36,9 \%)$ \\
\hline Inne & $7(23,3 \%)$ & $4(8 \%)$ & - & $1(1,5 \%)$ \\
\hline Ogółem & $30(100 \%)$ & $50(100 \%)$ & $15(100 \%)$ & $65(100 \%)$ \\
\hline
\end{tabular}

Źródło: opracowanie własne.

Na podstawie przeprowadzonych badań i dokonanej analizy formułuję następujące wnioski:

- Rodzice biorący udział w badaniach dobrze oceniają działalność szkół polskich na obczyźnie - dotyczy to wszystkich badanych placówek. 
- Rodzice potrafią krytycznie spojrzeć na działalność szkół z polskim językiem nauczania, choć jak sami przyznają, nie mają wobec pracy szkoły zbyt wielu zastrzeżeń. Pojawiające się w ich relacjach uwagi odnoszą się raczej do poprawy ogólnego wizerunku szkoły i usprawnienia jej działań. Respondenci potrafią określić, które elementy w jej działalności nie funkcjonują poprawnie (np. oddziaływanie władz lokalnych, państwowych czy niewystarczające zaangażowanie samych rodziców, mała liczba uczniów). Jednocześnie określają, jak - ich zdaniem - poprawić potencjalne niedomagania (zwiększenie zaangażowania podmiotów wewnętrznych - społeczności szkolnej oraz zewnętrznych instytucji lokalnych, wzbogacenie oferty edukacyjnej i in.).

- Badani rodzice cenią sobie fakt, że polskie placówki edukacyjne za granicą w ogóle działają. Jednak w ich opiniach wyczuwalny jest żal do polskich władz państwowych, ponieważ odbiera się szkole rangę szkoły na rzecz SKP. Dodatkowo pojawiają się opinie o niewystarczającym finansowaniu placówek. Rodzice podkreślają, że istotna - w ich ocenie - jest wysoka jakość kształcenia uczniów w polskich szkołach, o którą należy dbać, by nie obniżyć poziomu nauczania, a jednocześnie starać się dążyć do jego podwyższenia. Główny cel pracy szkoły - przekaz wartości narodowych, języka i kultury - nie budzi żadnych uwag.

W nawiązaniu do słów Zenona Jasińskiego o potrzebie funkcjonowania szkół z polskim językiem nauczania wraz ze społeczeństwem większościowym uznaję, że w badanych placówkach nie zachodzi konflikt interesów, a prowadzona przez szkoły działalność edukacyjna i kulturalna wpisuje się w lokalny krajobraz każdego badanego środowiska. Prowadzenie działalności stanowiącej pomost pomiędzy dwoma światami kultur (kraju pochodzenia i pobytu) najbardziej widoczna jest na obszarze Czeskiego Cieszyna, to jednak wiąże się przede wszystkim ze specyfiką pracy realizowanej w szkole. W szkołach z polskim językiem nauczania prowadzących działalność przy polskich placówkach dyplomatycznych bardziej widoczne są działania skoncentrowane na edukacji narodowej, a łącznikami ze środowiskiem większościowym pozostają przedstawiciele społeczności.

\section{Podsumowanie}

W zaprezentowanym szkicu omówiono wybrane zagadnienia dotyczące działalności szkół z polskim językiem nauczania w opiniach rodziców uczniów tych szkół. Zarysowany przez respondentów obraz szkół polskich jest dość pozytyw- 
ny, choć pojawiają się pewne niedociągnięcia czy sprzeczne z ich oczekiwaniami działania (lub wręcz przeciwnie - brak pewnych spodziewanych działań).

Struktura społeczeństwa europejskiego jest coraz bardziej niejednorodna narodowościowo, a szkolnictwo mniejszościowe jest miejscem kontaktu z innymi rodakami poza krajem pochodzenia. Dla dzieci emigrantów szkoła (poza rodziną) stanowi miejsce kształtowania i podtrzymywania tożsamości narodowej, nauki kultury polskiej i polskich tradycji. W szkole dzieci poznają i utrzymują kontakt z językiem polskim, historią i geografią kraju pochodzenia swojego bądź tylko przodków. W dobie wzmożonych ruchów ludności działalność edukacyjna szkół polskich jest konieczna i oczekiwana przez adresatów - Polaków przebywających za granicą. To dla nich działalność szkół (i Szkolnych Punktów Konsultacyjnych - SKP) jest wizytówką naszego kraju. O tym, jaka będzie ta wizytówka i obraz Polski w krajach europejskich (i na świecie) już w kolejnych latach, będzie decydować zarówno władza państwowa, jak i społeczność szkół prowadzących naukę w języku polskim, a w przyszłości absolwenci tych szkół.

Zamiast zakończenia pragnę przytoczyć słowa Jolanty Muszyńskiej i Urszuli Namiotko, które oddają sens organizacji Polaków w szkolnych placówkach edukacyjnych poza granicami kraju: „Szkoła jest instytucją państwową i społeczną organicznie związaną i połączoną z narodem. Szkoły polskie, funkcjonujące poza obszarem państwa polskiego, mają ogromne znaczenie w wychowaniu dzieci w duchu poszanowania tradycji i wiary Ojców, w duchu honoru i patriotyzmu. Działalność szkół to nie tylko nauka języka polskiego, nie tylko pozostawanie w kręgu kultury polskiej, ale przede wszystkim kształtowanie i umacnianie polskiej tożsamości narodowej" (Muszyńska i Namiotko, 2010, s. 63).

\section{Bibliografia}

Danilewicz, W. 2006. Sytuacja życiowa dzieci w rodzinach migracyjnych. Białystok: Wydawnictwo Uniwersyteckie „Trans Humana”.

Danilewicz, W. 2007. Społeczne konsekwencje migracji zagranicznych. W: Lalak, D. (red.): Migracja - uchodźstwo - wielokulturowość. Zderzenie kultur we współczesnym świecie. Warszawa: Wydawnictwo Akademickie „Żak”, ss. 152-166.

Danilewicz, W. 2010. Rodzina ponad granicami. Transnarodowe doświadczenia wspólnoty rodzinnej. Białystok: Wydawnictwo Uniwersyteckie „Trans Humana”. 
http://www.aktualnosci.pan.pl/index.php/77-uncategorised/1382-raport-komitetu-badan-nad-migracjami-pan-w-kwestii-skutkow-emigracji-mieszkancow-polski-do-krajow-unii-europejskiej. 9.01.2014 (www-4).

http://www.polska-szkola.pl/index.php/dla-rodzicow/oswiata-polonijna. 20.08.2019 (www-6)

http://www.orpeg.pl/. 20.08.2019 (www-7).

http://wiadomosci.gazeta.pl/wiadomosci/1,114871,15153711,PAN_alarmuje_Przez_emigracje_spada_liczba_urodzen.html\#MT. 9.01.2014 (www-3). Szałtys, D. red. 2018. Informacja o rozmiarach $i$ kierunkach czasowej emigracji z Polski w latach 2004-2017. GUS. W: https://stat.gov.pl/obszary-tematyczne/ludnosc/migracje-zagraniczne-ludnosci/informacja-o-rozmiarach-i-kierunkach-czasowej-emigracji-z-polski-w-latach-2004-2017,2,11. html (www-2).

Jasiński, Z. 2010. Problemy szkolnictwa i oświaty polonijnej w kontekście wielokulturowości - uwagi ogólne. W: Lewowicki, T., Nikitorowicz, J. i Szczurek-Boruta, A. red. Szkolnictwo z polskim językiem nauczania w państwach europejskich - stan, problemy, perspektywy. Białystok - Cieszyn - Warszawa: Uniwersytet w Białymstoku, WEiNoE UŚ, WSP ZNP w Warszawie, SWEM, ss. 15-38.

Koprukowniak, A. 1995. Szkolnictwo polonijne na świecie. Zarys syntezy. Lublin: UMCS.

Leśniak, M. 2009. Emigracja zarobkowa - rodzina polska w nowej rzeczywistości społeczno-wychowawczej. Pedagogika Rodziny. 1 (4), ss. 127-134.

Lewowicki, T. 2013. O przybliżenie spraw szkolnictwa dla mniejszości narodowych i etnicznych - perspektywa edukacji międzykulturowej. W: Lewowicki, T., Nikitorowicz, J. i Szczurek-Boruta A. red. Szkoty dla mniejszości narodowych i społeczności kaszubskiej w Polsce - stan, problemy. perspektywy. Warszawa - Cieszyn - Białystok: Wyższa Szkoła Pedagigiczna ZNP w Warszawie, Uniwersytet Śląski w Katowicach, Uniwersytet w Białymstoku, SWEM, ss. 11-20.

Mioduszewska M,. 2008. Najnowsze migracje z Polski w świetle danych Badania Aktywności Ekonomicznej Ludności. Warszawa: Ośrodek Badań nad Migracjami UW.

Muszyńska, J. i Namiotko, U. 2010. Szkoty polskie na Litwie. W: Lewowicki, T., Nikitorowicz, J. i Szczurek-Boruta, A. red. Szkolnictwo z polskim językiem nauczania w państwach europejskich - stan, problemy, perspektywy. Białystok - Cieszyn - Warszawa: Uniwersytet w Białymstoku, WEiNoE UŚ, WSP ZNP w Warszawie, SWEM, ss. 63-82. 
Narodowy Spis Powszechny Ludności i Mieszkań 2011. Migracje zagraniczne ludności (2013). GUS, Warszawa. http://www.stat.gov.pl/cps/rde/xbcr/gus/L_migracje_zagraniczne_ludnosci_NSP2011.pdf. 26.11.2013 (www-1). Nikitorowicz, J. i Misiejuk, D. 2009. Wstęp. W: Nikitorowicz, J. i Misiejuk, D. red. Procesy migracji w społeczeństwie otwartym. Perspektywa edukacji międzykulturowej. Białystok: Wydawnictwo Uniwersyteckie „Trans Humana", ss. 9-12.

Program Rozwoju Oświaty Polskiej za Granicą i Oświaty Polonijnej na lata 2009-2011. Materiat do dyskusji (2009). MEN, Warszawa. W: http://www. polska-szkola.pl/file.php/1/moddata/forum/32/25/plan_dzialan_projekt. pdf. 10.12.2017 (www-8).

Szczygielska, I. 2013. Migracje zarobkowe kobiet $i$ ich wptyw na funkcjonowanie rodzin. Warszawa: UW.

Szukalski, P. 2017. Małżeństwa i rozwody. W: Potrykowska, A. red. Sytuacja demograficzna Polski. Raport 2016-2017. Warszawa: Rządowa Rada Ludnościowa, ss. 79-98.

Ślusarczyk, M. 2010. Demograficzne i społeczne aspekty migracji Polaków na początku XX wieku. W: Grzymała-Moszczyńska, H., Kwiatkowska, A. i Roszak, J. red. Drogi i rozdroża. Migracje Polaków w Unii Europejskiej po 1 maja 2004 roku. Analiza psychologiczno-socjologiczna. Kraków: Zakład Wydawniczy „NOMOS”, ss. 15-32.

Walczak, B., Kozdrowicz, E. i Bielecka, E. 2009. Społeczne i pedagogiczne skutki migracji poakcesyjnych. W: Nikitorowicz, J., i Misiejuk, D. red. Procesy migracji w społeczeństwie otwartym. Perspektywa edukacji międzykulturowej. Białystok: Wydawnictwo Uniwersyteckie „Trans Humana”, ss. 200-212.

Założenia Projektu Programu Rozwoju Oświaty Polskiej za Granica i Oświaty Polonijnej. 2009. MEN, Warszawa. W: http://www.polska-szkola.pl/file. php/1/MEN_-_komentarz_do_strategii_oswiaty_polskiej_za_granica_. pdf. 10.12.2013 (www-5).

\section{Schools with Polish as the teaching language as a challenge for the $21^{\text {st }}$ century education - selected issues}

Abstract: What has a permanent place in modern educational space is the school system for national minorities, including Poles living in a foreign land. The increasing social mobility and a large number of Polish citizens living abroad neces- 
sitate the adjusting of the Polish educational offer for the youngest (children and youth) - also outside Poland.

In the presented study, the authoress discusses the significance and consequences of contemporary migration and describes the network and offer of schools with Polish as the teaching language. The research results are also discussed of the studies conducted in Polish educational institutions abroad in selected schools (in Austria, France, and the Czech Republic), which allows for specifying the major problems and parental expectations concerning these institutions. The work is completed with a recapitulation. The study constitutes an introduction to broader research into the activity and functioning of schools with Polish as the teaching language and of the agents (learners, teachers, parents) tightly related to their activity.

Keywords: schools with Polish as the teaching language abroad, migration of population, education 